\title{
Some aspects of molecular diagnostics in Lynch syndrome
}

\author{
Grzegorz Kurzawski \\ International Hereditary Cancer Center, Department of Genetics and Pathology, Szczecin, Poland, Email: gkurz@sci.pam.szczecin.pl
}

Key words: diagnostic criteria, molecular diagnostics, germline MSH2 and MLHI mutations

Submitted: 13 November 2006

Accepted: 5 December 2006

\begin{abstract}
This manuscript is composed of five parts which summarize five publications in succession. Essentially, they are concerned with molecular diagnostics of Lynch syndrome and are based on studies in 238 families. The finding that young age at diagnosis is the key feature in patients with MSH2 and MLH1 mutations (Part 1) has helped to define simple criteria for the preliminary diagnosis of this syndrome. A cheaper method for the detection of mutations has been developed (Part 2) and applied to study the types of mutations and their prevalence in Poland (Part 3) and the Baltic States (Part 4). A specific feature of these mutations, i.e. presence of recurrent mutations in the majority of affected families with mutations, has suggested the feasibility of effective diagnostics with a single test disclosing all of them. An attempt to reveal other causes of familial aggregation of colorectal cancer has ruled out any association with $\mathrm{C}$ insertion in the NOD2 gene (Part 5).
\end{abstract}

\section{Introduction}

More than 90 years ago, Warthin described a family in which members from several generations died at a young age because of colorectal cancer (CRC) or carcinoma of the endometrium [1]. The clinical characteristics of this disorder, called hereditary non-polyposis colorectal cancer (HNPCC) or Lynch syndrome, which was the reason for the early dead cases in that family, were shown many years later by Lynch [2]. The members of families with Lynch syndrome are particularly at risk of developing cancers of the colon and endometrium inherited as monogenic disorders with high penetration in an autosomal dominant manner. Today it is well known that this disorder results from a mutation carrier state in one of the mutator genes and can be defined as hereditary deficiency of mismatch repair (MMR) activity. There are at least four genes definitely associated with HNPCC, and these include MLH1 [3], MSH2 [4], MSH6 [5] and PMS2 [6]. Two further genes, MLH3 and
PMS1, have also been implicated in HNPCC, but their role is less clear [7-9]. The majority of mutations lead to truncation of the encoded protein (based on the Insight database - http://www.insight-group.org/). Usually, pathogenicity of mutations is caused by the loss of an important protein domain or a change of structure in the site of interaction with other mismatch repair proteins. Deficiency of MMR activity manifested as microsatellite instability (MSI) and loss of expression of mutated genes in cancer has been used as a preselective factor in many diagnostic procedures, also investigated by the author $[10,11]^{*}$.

At first, diagnosis of this syndrome was based mainly on the Amsterdam criteria (Table 1), which were proposed by the International Collaborative Group on HNPCC - ICG-HNPCC [12].

Afterwards, these criteria were expanded [13] by adding cancers characteristic for HNPCC tumours such as: endometrium, small intestine, urinary tract (HNCCP related cancer - HNPCC-rc). Despite all the 
Table 1. Diagnostic criteria of HNPCC according to ICG-HNPCC

\begin{tabular}{|c|c|}
\hline Amsterdam criteria I & Amsterdam criteria II \\
\hline $\begin{array}{l}\text { Colorectal cancer confirmed histologically in at least three } \\
\text { affected relatives, one of whom is a first-degree relative } \\
\text { of the other two }\end{array}$ & $\begin{array}{l}\text { Cancer }{ }^{1} \text { confirmed histologically in at least three affected relatives, } \\
\text { one of whom is a first-degree relative of the other two }\end{array}$ \\
\hline At least two first-degree relatives in two successive generations & At least two first-degree relatives in two successive generations \\
\hline $\begin{array}{l}\text { At least one member diagnosed with colorectal cancer } \\
\text { before age } 50 \text { years }\end{array}$ & At least one member diagnosed with cancer ${ }^{1}$ before age 50 years \\
\hline Familial adenomatous polyposis has been excluded & Familial adenomatous polyposis has been excluded \\
\hline
\end{tabular}

Table 2. Park I criteria for suspected HNPCC families (according to [16 $]^{*}$ ). At least one item in each category must be met (A or B) and (C or $\mathrm{D}$ or $\mathrm{E})$

\begin{tabular}{ll}
\hline Category I & Category II \\
\hline A - vertical transmission of colorectal cancer & C - multiple colorectal tumours (including polyps) \\
\hline B - at least two siblings affected with colorectal cancer in a family & D - at least one colorectal cancer diagnosed before the age of 50 years \\
\hline- & $\begin{array}{c}\text { E - development of extracolonic cancer (endometrium, small intestine, } \\
\text { urinary tract, stomach, hepatobiliary system or ovary) } \\
\text { in family members }\end{array}$ \\
\hline
\end{tabular}

modifications, it appears that their sensitivity was not adequate. In a population tested by Syngal et al. [14], $39 \%$ of families with MSH2 and MLH1 mutations did not fulfil the Amsterdam criteria. Better criteria, concerning sensitivity, were the Bethesda criteria [15], which were not sufficiently specific. The criticism of the Amsterdam criteria led to the definition of other criteria, which could not be as specific as previous, but which have greater application in practical diagnosis. These criteria, acknowledged by an international group of specialists from ICG-HNPCC, were in year 2000 the Parks criteria (developed by using information about families with mutations detected in the Pomeranian Academy of Medicine in Szczecin) [16] ${ }^{*}$, which were modified later [17]*.

Analysis of information from the literature, related to correlation between occurrence of constitutional mutations in the MSH2 and MLH1 genes, and the clinical and pedigree features, allowed the hypothesis to be made that in families with CRC aggregation unclassified to the Amsterdam criteria prevalence of $\mathrm{MSH} 2$ and $\mathrm{MLH} 1$ gene mutations is very high and sequencing without any pre-selection can be applied if cancers are diagnosed at early age $[14,18-22]$.

\section{PART 1}

\section{Age at diagnosis of colorectal cancer as a predictor of mutations of MSH2 and MLHI genes in families suspected of HNPCC (Based on publication no. 1: Age at diagnosis of cancer as predictor of mutation occurrence in families suspected of HNPCC [23]*)}

Analysis of significance of age at cancer diagnosis as a factor allowing identification of a subgroup of patients with a high frequency of $\mathrm{MSH} 2$ and $\mathrm{MSH} 1$ mutations among families that fulfil suspected HNPCC criteria was performed. In this study frequency of mutation of $\mathrm{MSH} 2$ and $\mathrm{MLH} 1$ was compared between groups of patients matching the Park I criteria and discriminated by the age of diagnosis. DNA from thirtyone unrelated patients affected by colorectal cancer from families matching the above criteria [16]* (Table 2) was studied by direct sequencing for occurrence of $\mathrm{MSH} 2$ and $\mathrm{MSH} 1$ gene mutations.

Seven mutations were detected: five in the MLHT gene and two in the MSH2 gene. All seven mutations were found in a subgroup of 19 patients with cancer diagnosed before the age of 50 years. In a subgroup 
Table 3. Modified criteria for suspected HNPCC families

I - at least one HNPCC cancer (colorectal, endometrial, small intestine, urinary tract) has been diagnosed in first-degree relatives of patient with colorectal cancer

II - at least one of them was diagnosed before the age of 50 years

III - FAP has been excluded

of 12 patients with cancer diagnosed at an older age only one case of $\mathrm{MLH} 7$ alteration of unknown significance was detected. Our results indicate that early age at cancer diagnosis seems to be a crucial pedigree factor in discrimination of patients with $\mathrm{MSH} 2$ or MLH1 mutations among families suspected of HNPCC and matching Park's criteria I.

The meaning of criteria of age at diagnosis and presence of at least two cancers diagnosed in first-degree relatives in kindreds was verified on greater genetic material, with cooperation of the Pomeranian Academy of Medicine in Szczecin with German and Danish scientists, entitled: Nuclear Pedigree Criteria of Suspected HNPCC [24]*. That canon has become the main standard, used in daily work with patients suspected of HNPCC. The criteria are summarized in Table 3.

Analysis of families with HNPCC based only on pedigree and clinical criteria is insufficient, because it did not allow definite identification of patients suspected of HNPCC, or eliminate from the group at risk patients without any mutations. Currently, clinical and pedigree criteria are used to pre-select patients diagnosed by molecular diagnostics.

\section{PART 2}

\section{Molecular techniques for the detection of mutations - mutation analysis of $M S H 2$ and $M L H 1$ genes using DHPLC (Based on publication no. 2: Mutation analysis of $M L H 1$ and MSH2 genes performed by denaturing high-performance liquid chromatography [25]*)}

The most sensitive mutation detection technique is considered to be direct sequencing. The first mutations in Polish families with HNPCC [26, 27]* were detected by the mentioned technique in the Pomeranian Academy of Medicine, Szczecin, Poland. However, sequencing of $\mathrm{MLH} 1$ and $\mathrm{MSH} 2$ genes is technically demanding, timeconsuming and expensive for Polish economic conditions. Reduction of costs was possible by using a cheaper screening method to detect changes in DNA and reduce DNA sequencing only to confirm this. The Pomeranian Academy of Medicine in Szczecin initially tried to obtain some savings using single-strand conformation polymorphism (SSCP). Unfortunately these techniques were not sensitive enough to detect mutations as well as direct sequencing. Also the trial of reduction of cost by sequencing cDNA obtained by reverse transcription of DNA to detect mutations [28]* turned out not to be sufficiently helpful in practice. The main reason for that was the difficulty in organization to achieve suitable quality of material to isolate RNA.

Studies show very high sensitivity of denaturing high-performance liquid chromatography (DHPLC) in detection of mutations of different genes [29], which leads us in the current paper to make an attempt to develop an economical version of this method, in relation to $\mathrm{MLH1}$ and $\mathrm{MSH} 2$ - the main genes connected with HNPCC. It was based on establishing of optimal terms of chromatographic development: the temperature and gradient profile for 36 amplicons of MLH1 and MSH2 genes. We investigated the sensitivity and specificity of DHPLC analysis for the detection of mutations. For the studies we took 46 patients with CRC from families with HNPCC. 19 patients had previously been identified by DNA sequencing. In 27 patients (who had not previously been tested) 16 rare changes were detected, including 4 mutations not described earlier in other populations. Generally, we did not observe false positive or false negative results. Elution profiles were highly characteristic for a given change and in $98.5 \%$ of cases allowed the distinction between novel alterations and previously identified mutations and polymorphisms. For the detection of changes in almost all amplicons, it was sufficient to use just one denaturing temperature. Results of this study support that DHPLC is a highly sensitive, specific and cost-effective technique with a particularly high potential for diagnostic laboratories involved in the identification of MSH2 and MLH1 gene mutations.

\section{PART 3}

\section{Types and prevalence of MSH2 and MLHI mutations in HNPCC families from Poland (Based on publication no. 3: Germline MSH2 and MLH1 mutational spectrum including large rearrangements in HNPCC families from Poland (update study) [30]*)}

Currently, 448 different mutations from different populations have been reported in these genes as 
described in the Insight Group Database. MLH1 and MLH2 genes show abnormalities in almost $90 \%$ of HNPCC families with identified germline mutations. The majority of reported $\mathrm{MLH} 1$ and $\mathrm{MSH} 2$ mutations are dispersed throughout the 35 exons of these two genes. The majority of mutations are frameshift or nonsense mutations that lead to truncated proteins. Recently it has been suggested that genomic deletions of one or more exons account for a significant percentage of the $\mathrm{MSH} 2$ and $\mathrm{MLH} 1$ mutations [32-38]. Many of the MSH2 and MLH1 changes including large deletions are recurrent and are described as founder mutations in particular populations $[33,35-44]$. To develop efficient DNA-testing protocols, it is important to describe the nature and frequency of mutations in different ethnic groups. Herein, we describe the results of analyses of detecting MSH2 and MLH1 gene mutations in a series of 226 HNPCC families from all regions of Poland (among all publications of that kind, this is the biggest in Eastern Europe and one of the biggest in the whole world)

DNA was extracted directly from blood leukocytes. To confirm some mutations, RNA-sequencing and tissues from paraffin block were also used. RNA-sequencing template was used for patients with deletions detected by the MLPA assay of genomic DNA. Some of the mutations were confirmed by immunohistochemical staining of tumour tissues. For the studies we took unrelated patients from families matching the Amsterdam II criteria or at least our modified criteria (Table 3). Patients used for this study were ascertained from the following regions: Białystok - 2, Bydgoszcz - 9, Bytom - 2, Gdańsk - 10, Gliwice - 1, Gorzów - 3, Jelenia Góra - 1, Kielce - 18, Koszalin - 4, Kraków - 7, Legnica - 4, Lublin - 4, Łódź - 3, Olsztyn - 27, Opole - 6, Poznań - 13, Rzeszów - 2, Szczecin - 71, Świdnica - 7, Świnoujście - 1, Warszawa - 3, Wrocław - 16 and Zielona Góra - 12.

This study was approved by the Institutional Human Ethics Review committee of the Pomeranian Medical University.

Among 78 families, 50 different pathogenic mutations were found, 25 in MSH2 and 25 in MLH1 (Table 4).

Twenty-four mutations have not been described earlier in other populations. Among 78 families with $\mathrm{MLH} 1$ and MSH2 mutations, 54 (69.2\%) were affected by recurrent mutations including 38 found at least twice in our own series. Two of the most frequent alterations were a substitution of $A$ to $T$ at the splice donor site of intron 5 of $M S H 2$, which is the most common mutation in the world connected with HNPCC [45], and a missense change (A681T) of MLH1 found in 10 and 8 families, respectively.

Using MLPA analyses revealed 7 patients with 6 different deletions. This equates to almost $10 \%$ of probands with identifiable MSH2 and MLH1 mutations. Five different deletions were detected in MSH2. Two of these showed loss of single exon 9, which is located between two large introns.

Our results indicate that a screening protocol that is limited to the detection of all reported mutations will result in the identification of the majority of changes present in MLH1 and MSH2 genes in Polish HNPCC kindreds.

\section{PART 4}

\section{Types and prevalence of MSH2 and MLHI mutations in HNPCC families from the Baltic States (Based on publication no. 4: Germline MSH2 and MLHI mutational spectrum in HNPCC families from Poland and the Baltic States [46]*)}

Genetic disease shows population distinctiveness at a molecular and clinical level. However, some changes are recurrent and are described as founder mutations in particular populations. To develop efficient DNA testing, it is important to describe the nature and frequency of mutations that are characteristic of particular ethnic groups. The $\mathrm{MSH} 2$ and $\mathrm{MLH} 1$ mutation spectrum has been investigated in the Eastern Europe region by the author in a paper from 2002 [46]*. We screened 101 HNPCC kindreds fulfilling the Amsterdam II diagnostic criteria or our suspected HNPCC criteria (Table 3). The results concerning 89 Polish families were described in Part 3 of the current paper. Also there were 12 families tested, 6 from Lithuania, 3 from Latvia and 3 from Estonia. Among patients from the Baltic States, there were found two mutations and one change suspected of pathogenic character. Two of the most frequent mutations identified in Poland were also found in Lithuanian families, suggesting a common history. Poland and the Baltic States may have more common mutations than reported here since the number of samples from Estonia, Latvia and Lithuania were too small to make the appropriate comparisons.

In summary, it seems likely that the MSH2 and MLH1 changes described here are representative of the majority of HNPCC mutations in families from this region. Therefore, we believe it is justified to develop a DNA testing strategy based on the preferential analysis of changes identified from this population. 
Table 4. Germline MSH2 and MLH1 mutations in Polish HNPCC families

\begin{tabular}{|c|c|c|c|c|c|}
\hline $\begin{array}{l}\text { Mut. } \\
\text { No. }\end{array}$ & $\begin{array}{l}\text { Gene/exon } \\
\text { or intron }\end{array}$ & $\begin{array}{l}\text { Position of nucleotide } \\
\text { with mutation }\end{array}$ & Consequence & $\begin{array}{l}\text { Number } \\
\text { of families }\end{array}$ & $\begin{array}{l}\text { Reported in other } \\
\text { populations }\end{array}$ \\
\hline 1. & $\mathrm{MSH} 2 / 1$ & c. $4 \mathrm{G}>\mathrm{A}$ & $\mathrm{A} 2 \mathrm{~T}$ & 1 & yes \\
\hline 2. & $\mathrm{MSH} 2 / 1-6$ & unknown & del ex1-6 in DNA ${ }^{1}$ & 1 & $?$ \\
\hline 3. & $M S H 2 / 2$ & del/ins ${ }^{2}$ & Premature nonsense codon & 1 & no \\
\hline 4. & $\mathrm{MSH} 2 / 3-6$ & unknown & del ex3-6 in DNA & 1 & $?$ \\
\hline 5. & $\mathrm{MSH} 2 / 3$ & c. $435 \mathrm{~T}>\mathrm{G}$ & $145 \mathrm{M}$ & 1 & yes \\
\hline 6. & $\mathrm{MSH} 2 / 3$ & c.613G > T & E205X & 1 & no \\
\hline 7. & MSH2/SD3 & c. $645+\mathrm{lg}>t$ & del ex3 no reading frame shift & 1 & no \\
\hline 8. & $\mathrm{MSH} 2 / 4$ & c.715 C>T & Q239X & 1 & no \\
\hline 9. & MSH2/SD5 & c. $942+3 a>t$ & del ex5 no reading frame shift & 10 & yes \\
\hline 10. & MSH2/7 & c. $1204 C>T$ & Q402X & 1 & no \\
\hline 11. & $\mathrm{MSH} 2 / 7$ & c. $1215 \mathrm{C}>\mathrm{A}$ & Y405X & 1 & no \\
\hline 12. & $\mathrm{MSH} 2 / 7$ & c. $1216 C>T$ & R406X & 2 & yes \\
\hline 13. & $\mathrm{MSH} 2 / 7-16$ & unknown & del ex7-16 in DNA3 & 1 & $?$ \\
\hline 14. & $\mathrm{MSH} 2 / 8$ & unknown & del ex8 in $\mathrm{DNA}^{4}$ & 1 & $?$ \\
\hline 15. & MSH2/9 & unknown & del ex in DNA 4 & 2 & $?$ \\
\hline 16. & $\mathrm{MSH} 2 / \mathrm{SD} 10$ & $c .1661+5 g>c$ & del ex10 with reading frame shift & 1 & no \\
\hline 17. & MSH2/11 & c. 1705-1706delGA & reading frame shift & 1 & no \\
\hline 18. & $\mathrm{MSH} 2 / 12$ & c.1771-1772insA & reading frame shift & 1 & no \\
\hline 19. & $\mathrm{MSH} 2 / 12$ & c. $1968 C>G$ & R656X & 1 & yes \\
\hline 20. & $\mathrm{MSH} 2 / 13$ & c. $2131 \mathrm{C}>\mathrm{T}$ & R711X & 1 & yes \\
\hline 21. & MSH2/SD13 & $c .2210+1 \mathrm{~g}>\mathrm{c}$ & del ex13 with reading frame shift & 1 & no \\
\hline 22. & MSH2/14 & c.2305delT & reading frame shift & 1 & no \\
\hline 23. & MSH2/14 & c.2388delT & reading frame shift & 1 & no \\
\hline 24. & MSH2/14 & c. $2422 \mathrm{G}>\mathrm{T}$ & E808X & 2 & no \\
\hline 25. & MSH2/SD15 & c. $2634+1 \mathrm{~g}>\mathrm{a}$ & del ex15 with reading frame shift & 1 & yes \\
\hline 26. & $M L H 7 / 1$ & c.37delG & reading frame shift & 1 & no \\
\hline 27. & $\mathrm{MLHT} / 1$ & c.66delG & reading frame shift & 1 & yes \\
\hline 28. & $\mathrm{MLHT} / 1$ & c. $83 \mathrm{C}>\mathrm{T}$ & P28L & 3 & yes \\
\hline 29. & $\mathrm{MLHT} / 2$ & c.161delG & reading frame shift & 1 & no \\
\hline 30. & $\mathrm{MLHT} / 2$ & c. $184 \mathrm{C}>\mathrm{T}$ & Q62X & 2 & yes \\
\hline 31. & $\mathrm{MLHT} / 2$ & c. $199 \mathrm{G}>\mathrm{A}$ & G67R & 1 & yes \\
\hline 32. & $\mathrm{MLHI} / 3$ & c. $256 \mathrm{C}>\mathrm{T}$ & Q86X & 1 & no \\
\hline 33. & $\mathrm{MLHT} / 4$ & c. $350 C>T$ & $\mathrm{T1} 17 \mathrm{M}$ & 1 & yes \\
\hline 34. & $M L H 7 / 4$ & c.356-357insAA & reading frame shift & 1 & no \\
\hline 35. & $\mathrm{MLHT} / 5$ & c. $392 \mathrm{C}>\mathrm{A}$ & $\mathrm{S} 131 \mathrm{X}$ & 1 & no \\
\hline 36. & MLHI/7SA & c. $546-2 a>g$ & del ex7 with reading frame shift & 1 & yes \\
\hline 37. & $\mathrm{MLHT/SD8}$ & c. $677 \mathrm{G}>\mathrm{T}$ & del ex8 with reading frame shift & 3 & yes \\
\hline 38. & $\mathrm{MLHI} / 10$ & g.37019613-37020677del1064 & del ex10 in DNA 4 & 1 & no \\
\hline 39. & MLH1/SD10 & c.883delAGgt & del ex10 with reading frame shift & 1 & no \\
\hline 40. & MLH1/SD10 & $c .883 A>C(c .884-2 A>C)$ & del ex10 with reading frame shift & 1 & no \\
\hline 41. & $\mathrm{MLHI} / 12$ & c.1252-1253delGA & reading frame shift & 1 & no \\
\hline 42. & $\mathrm{MLHI} / 12$ & c. $1321 \mathrm{G}>\mathrm{A}$ & $\mathrm{A} 441 \mathrm{~T}$ & 3 & yes \\
\hline 43. & MLHT/SD12 & c. $1409+1 \mathrm{~g}>c$ & del ex 12 with reading frame shift & 1 & yes \\
\hline 44. & $\mathrm{MLHT} / 13$ & c.1489-1490insC & reading frame shift & 3 & yes \\
\hline 45. & $\mathrm{MLHT} / 15$ & c. $1672 \mathrm{G}>\mathrm{T}$ & E558X & 1 & yes \\
\hline 46. & $\mathrm{MLHT} / 15$ & c. $1731 \mathrm{G}>\mathrm{A}$ & del ex15 with reading frame shift & 1 & yes \\
\hline 47. & $\mathrm{MLHT} / 16$ & c. 1852-1854delAAG & 618delK & 1 & yes \\
\hline 48. & $\mathrm{MLHl} / 18$ & c. $2040 \mathrm{C}>\mathrm{A}$ & C680X & 1 & no \\
\hline 49. & $\mathrm{MLHT} / 18$ & c. $2041 G>A$ & $\mathrm{~A} 681 \mathrm{~T}$ & 8 & yes \\
\hline 50. & $\mathrm{MLHI} / 19$ & c.2223delGCAGCTTGCTA & reading frame shift & 1 & no \\
\hline
\end{tabular}

? - definite answer is difficult without breakpoint sequencing

mutations not found previously in other populations shown in bold;

1 probably no transcript of mutant allele; ${ }^{2}$ c.243delTAAAATGAATTTTGAATCTTTTGTAAAAGATins CTGACAAGCGCCTATAGCA

CTCGAATAATTCTTCTCACCCTAACAGGTCAGCCTCGCTTCCCAGCCCTCACTAACAT

TAACGAAAACAACCCACCCTACTAAACCCCATTAAACGCCTAACAATCGGAAGCCTA

TTTTGCAGGGTTTCTCCATCACCAACAGCATTCTCCCCACATCCACCCCCCAAATGAC

AATCCCACTTTACTTAAAACTCACAG (premature nonsense codon in bold); ${ }^{3}$ shorter transcript of allele with deletion; ${ }^{4}$ exon deleted and reading frame shiff. 


\section{PART 5}

\section{Mutations of genes unrelated to MMR as a possible aetiological factor in Lynch syndrome (Based on publication no. 5: The NOD2 3020insC mutation and the risk of colorectal cancer [47]*)}

Lynch syndrome generally results from a mutation carrier state in MSH2 or MLH1 genes. Occasionally, similar clinical and pedigree characteristics may be due to mutations in a variety of other genes, including APC [48], TGF $\beta R I I$ [49], CDH1 [50], EXO1 [51] and MYH [52]. With rare exceptions (EXOI), tumours from such families do not display MSI. Since mutations in the NOD2 gene were associated with Crohn's disease $(C D)$ and a risk of colorectal cancer was suggested to be increased in this disorder [53], the author has made an attempt to answer the question whether the carrier state of insertion $\mathrm{C}$ could imitate clinical-pedigree characteristics of HNPCC.

The NOD2 gene comprises 12 exons and encodes a protein of 1040 amino acids [54]. The predicted motifs encoded by the NOD2 gene suggest that it is involved in the dysregulation of immune function by either affecting a change in the detection or binding of bacterial proteins and/or impaired nuclear factor $-\kappa B$ [55] signalling. Recently, three common variants have been identified that have been associated with an increased likelihood of $C D$, two of which are missense changes, and one an insertion mutation. The insertion mutation 3020ins $\mathrm{C}$ has been shown, when inherited in the homozygous state, to be associated with an almost 20 -fold risk of developing $C D$, whereas if present in the heterozygous state, it increases risk by $\sim 3$-fold [56].

The following groups of patients were taken for the studies:

- 156 patients with CRC matching the AMS II criteria or criteria of suspected HNPCC used in our centre but without MSH2 or MLH1 constitutional mutations;

- 250 consecutive patients with CRC diagnosed after 50 years of age from families without any clinical and pedigree features, leading to diagnosis of HNPCC definitely or with high probability;

- 50 consecutive patients with CRC diagnosed before 50 years of age from families without any clinical and pedigree features, leading to diagnosis of HNPCC definitely or with high probability;

- 100 CRC patients from the genetic counselling unit (of the International Hereditary Cancer Centre in Szczecin) from families where there were at least two other malignancies diagnosed on the same side of the family that confirmed an undefined cancer family aggregation;
- 300 consecutive newborns from the clinical hospitals of Szczecin.

DNA samples were obtained from the peripheral blood of CRC patients or from umbilical cord blood of newborns. The method described by Ogura [54] was used to identify the $3020 \mathrm{ins} C$ alteration. The sequences of the PCR products were confirmed by DNA sequencing.

There was no association between carrier-state of 3020 ins $C$ and prevalence aggregation of malignant adenoma (HNPCC and CFA) and with predisposition to CRC before 50 years of age. In contrast, frequency of that variant was considerably higher in the group of patients with CRC ( $n=250)$ diagnosed over 50 years of age than in the group of newborns $(O R=2.23 ; p=0.0046)$.

The results of the study show that DNA tests detecting the 3020ins C mutation can be used to detect increased predisposition to $C R C$ in a group of patients diagnosed after 50 years of age, who came from families without pedigree and clinical characteristics, allowing unequivocal identification of diseases or high probability of it.

\section{Summarization of results}

1. Constitutional mutations of $M S H 2$ and $M L H 1$ genes occur more frequently in families with suspected Lynch Syndrome, in which at least one member of the family is diagnosed under the age of 50 years.

2. Denaturing high-performance liquid chromatography shows sensitivity and specificity comparable to sequencing in detection of constitutional changes in $\mathrm{MLH} 1$ and $\mathrm{MSH} 2$ genes.

3. Characteristic features of the constitutional mutations detected in MLH1 and MSH2 genes in 78 Polish families with Lynch syndrome are the following:

a) Types and frequencies of changes are characteristic for the Polish population; around $50 \%$ of them (24 of 50 ) has been described for the first time;

b) The recurrent mutations account for a high percentage $-69.2 \%$, of all mutations; the two most frequent of them are c. $943+3 a>t$ in $M S H 2$ and c.2041G $>A$ in MLHT;

c) Mutations detected by sequencing or DHPLC account for $91 \%$ (71 of 78), and mutations detected by MLPA test (large deletions) account for $9 \%$ (7 of 78) of all mutations.

4. Mutations in MSH2 and $M L H 1$ genes identified in Poland have been found also in Lithuania.

5. The frequency of NOD2 3020ins C gene variant in families with HNPCC without mutation in $\mathrm{MLH} 1$ and MSH2 genes, was not increased. The 3020ins $\mathrm{C}$ variant in $C R C$ patients diagnosed above the age of 50 was found twice as frequently as in control group. 


\section{Conclusions}

1. Effective molecular diagnostics based on detection of the constitutional mutations in MSH2 and MLH1 genes is not only possible in families matching the Amsterdam II criteria, but also in HNPCC suspected families, in which at least one member of the family was diagnosed with cancer under the age of 50 years.

2. Application of the DHPLC method for detecting MSH2 and $\mathrm{MLH} 1$ gene mutations and the use of sequencing for only to confirmation and characterization of changes, contributes to substantial reduction of costs (about 10x) of molecular diagnostics in Lynch syndrome.

3. The results show that DNA screening tests, limited to detection of all mutations described in the present paper, allow identification of the majority of mutations present in MSH2 and MLH1 genes in Polish families with HNPCC.

4. DNA tests for detecting MSH2 and MLH1 gene mutations in Eastern Europe will probably be based on mutations identified for the first time in Poland.

5. DNA tests for detection of 3020insC in the NOD2 gene can be used to identify the increased risk of CRC, among patients above 50 years of age from families without any clinical and pedigree features of HNPCC diagnosed definitely or with high probability.

\section{References}

1. Warthin A S. Heredity with reference to carcinoma. Arch Intern Med 1913; 12: 546-555.

2. Lynch HT, Shaw MW, Magnuson CW, Larsen AL, Krush A Hereditary factors in cancer. Study of two large midwestern kindreds. Arch Intern Med 1966; 117: 206-212.

3. Papadopoulos N, Nicolaides NC, Wei YF, Ruben SM, Carter KC, Rosen CA, Haseltine WA, Fleischmann RD, Fraser CM, Adams $M D$, et al. Mutation of a mutL homolog in hereditary colon cancer. Science 1994; 263: 1625-1629.

4. Leach FS, Nicolaides NC, Papadopoulos N, Liu B, Jen J, Parsons R, Peltomaki P, Sistonen P, Aaltonen LA, Nystrom-Lathi M, et al. Mutations of a mutS homolog in hereditary nonpolyposis colorectal cancer. Cell 1993; 75: 1215-1225.

5. Akiyama Y, Sato H., Yamada T, Nagasaki H, Tsuchiya A, Abe R, Yuasa $Y$, et al. Germ-line mutation of the hMSH6/GTBP gene in atypical hereditary nonpolyposis colorectal cancer kindred. Cancer Res 1997; 57: 3920-3923.

6. Nicolaides NC, Papadopoulos N, Liu B, Wei YF, Carter KC, Ruben SM, Rosen CA, Haseltine WA, Fleischmann RD, Fraser CM, et al. Mutations of two PMS homologues in hereditary nonpolyposis colon cancer. Nature 1994; 371: 75-80.

7. Liu HX, Zhou XL, Liu T, Werelius B, Lindmark G, Dahl N, Lindblom A. The role of $\mathrm{hMLH} 3$ in familial colorectal cancer. Cancer Res 2003; 63: 1894-1899.

8. Liu T, Yan H., Kuismanen S, Percesepe A, Bisgaard ML, Pedroni $M$, Benatti P, Kinzler KW, Vogelstein B, Ponz de Leon M, Peltomaki P, Lindblom A. The role of hPMS1 and hPMS2 in predisposing to colorectal cancer. Cancer Res 2001; 61: 7798-7802.
9. Luo Y, Lin FT, Lin WC. ATM-mediated stabilization of hMutL DNA mismatch repair proteins augments p53 activation during DNA damage. Mol Cell Biol 2004; 24: 6430-6444.

10. * Debniak T, Kurzawski G, Gorski B, Kladny J, Domagala W, Lubinski J. Value of pedigree/clinical data, immunohistochemistry and microsatellite instability analyses in reducing the cost of determining $\mathrm{hMLH} 1$ and $\mathrm{hMSH} 2$ gene mutations in patients with colorectal cancer. Eur J Cancer 2000; 36: 49-54.

11. * Kurzawski G, Suchy J, Debniak T, Kladny J, Lubinski J. Importance of microsatellite instability (MSI) in colorectal cancer: MSI as a diagnostic tool. Ann Oncol 2004; 15 Suppl 4: iv283-iv284.

12. Vasen HF, Mecklin JP, Khan PM, Lynch HT. The International Collaborative Group on Hereditary Non-Polyposis Colorectal Cancer (ICG-HNPCC). Dis Colon Rectum 1991; 34: 424-425.

13. Vasen HF, Watson P, Mecklin JP, Lynch HT. New clinical criteria for hereditary nonpolyposis colorectal cancer (HNPCC, Lynch syndrome) proposed by the International Collaborative group on HNPCC. Gastroenterology 1999; 116: 1453-1456.

14. Syngal S, Fox EA., Eng C, Kolodner RD, Garber JE. Sensitivity and specificity of clinical criteria for hereditary non-polyposis colorectal cancer associated mutations in MSH2 and MLH1. J Med Genet 2000; 37: 641-645.

15. Rodriguez-Bigas MA, Boland CR, Hamilton SR, Henson DE, Jass JR, Khan PM, Lynch H, Perucho M, Smyrk T, Sobin L, Srivastava S. A National Cancer Institute Workshop on Hereditary Nonpolyposis Colorectal Cancer Syndrome: meeting highlights and Bethesda guidelines. J Natl Cancer Inst 1997; 89: 1758-1762.

16. * Park JG, Vasen HF, Park KJ, Peltomaki P, Ponz de Leon M, Rodriguez-Bigas MA, Lubinski J, Beck NE, Bisgaard ML, Miyaki M, Wijnen JT, Baba S, Lynch HT. Suspected hereditary nonpolyposis colorectal cancer: International Collaborative Group on Hereditary Non-Polyposis Colorectal Cancer (ICGHNPCC) criteria and results of genetic diagnosis. Dis Colon Rectum 1999; 42: 710-715.

17. * Park JG, Vasen HF, Park YJ, Park KJ, Peltomaki P, de Leon MP, Rodriguez-Bigas MA, Lubinski J, Beck NE, Bisgaard ML, Miyaki M, Wijnen JT, Baba S, Lindblom A, Madlensky L, Lynch HT. Suspected HNPCC and Amsterdam criteria II: evaluation of mutation detection rate, an international collaborative study. Int J Colorectal Dis 2002; 17: 109-114.

18. Heinimann K, Scott RJ, Buerstedde JM, Weber W, Siebold K, Attenhofer M, Muller H, Dobbie Z. Influence of selection criteria on mutation detection in patients with hereditary nonpolyposis colorectal cancer. Cancer 1999; 85: 2512-2518.

19. Lamberti C, Kruse R, Ruelfs C, Caspari R, Wang Y, Jungck M, Mathiak M, Malayeri HR, Friedl W, Saverbuch T, Propping P. Microsatellite instability-a useful diagnostic tool to select patients at high risk for hereditary non-polyposis colorectal cancer: a study in different groups of patients with colorectal cancer. Gut 1999; 44: 839-843.

20. Wang Q, Lasset C, Desseigne F, Saurin JC, Maugard C, Navarro C, Ruano E, Descos L, Trillet-Lenoir V, Bosset JF, Puisieux A. Prevalence of germline mutations of hMLH1, hMSH2, hPMS1, hPMS2, and hMSH6 genes in 75 French kindreds with nonpolyposis colorectal canser. Hum Genet 1999; 105: 79-85.

21. Wijnen JT, Vasen HF, Khan PM, Zwinderman AH, van der Klift H, Mulder A, Tops C, Moller P, Fodde R. Clinical findings with implications for genetic testing in families with clustering of colorectal cancer. N Engl J Med 1998; 339: 511 1-518.

22. Liu T, Wahlberg S, Burek E, Lindblom P, Rubio C, Lindblom A. Microsatellite instability as a predictor of a mutation in a DNA mismatch repair gene in familial colorectal cancer. Genes Chromosomes Cancer 2000; 27: 17-25.

23. * Kurzawski G, Debniak T, Kladny J, Lubinski J. Age at diagnosis of cancer as predictor of mutation occurrence in families suspected of HNPCC. J Appl Genet 2001 ; 42: 359-366. 
24. * Kladny J, Moslein G, Myrhoi T, Kurzawski G, Jakubowska A Debniak T, Petriczko W, Kozłowski W, Al-Amawi T, Brzosko M, Fliciński J, Jawień A, Banaszkiewicz Z, Rychter P, Lubinski J. Nuclear Pedigree Criteria of Suspected HNPCC. Hered Cancer Clin Pract 2003; 1: 34-38.

25. * Kurzawski G, Safranow K, Suchy J, Chlubek D, Scott RJ, Lubinsk J. Mutation analysis of MLH1 and MSH2 genes performed by denaturing high-performance liquid chromatography. J Biochem Biophys Methods 2002; 51: 89-100.

26. * Peltomaki P, Vasen HF. Mutations predisposing to hereditary nonpolyposis colorectal cancer: database and results of a collaborative study. The International Collaborative Group on Hereditary Nonpolyposis Colorectal Cancer. Gastroenterology 1997; 113: 1146-1158.

27. * Kurzawski G. Human gene mutations: MSH2, MLH1. Hum Genet 1999; 104: 116.

28. * Jakubowska A, Gorski B, Kurzawski G, Debniak T, Hadaczek P, Cybulski C, Kladny J, Oszurek O, Scott RJ, Lubinski J. Optimization of experimental conditions for RNA-based sequencing of $\mathrm{MLH}$ and MSH2 genes. Hum Mutat 2001; 17: 52-60.

29. Xiao W, Oefner PJ. Denaturing high-performance liquid chromatography: A review. Hum Mutat 2001; 17: 439-474

30. * Kurzawski G, Suchy J, Lener M, Klujszo-Grabowska E, Kladny J, Safranow K, Jakubowska K, Jakubowska A, Huzarski T, Byrski T, Debniak T, Cybulski C, Gronwald J, Oszurek O, Oszutowska D, Kowalska E, Gozdz S, Niepsuj S, Slomski R, Plawski A, LackaWojciechowska A, Rozmiarek A, Fiszer-Maliszewska L, Bebenek M, Sorokin D, Sasiadek MM, Stembalska A, Grzebieniak Z, Kilar E, Stawicka M, Godlewski D, Richter P, Brozek I, Wysocka B, Limon J, Jawien A, Banaszkiewicz Z, Janiszewska H, Kowalczyk J, Czudowska D, Scott RJ, Lubinski J. Germline MSH2 and MLH1 mutational spectrum including large rearrangements in HNPCC families from Poland (update study). Clin Genet 2006; 69: 40-47.

31. * Peltomaki P, Vasen H. Mutations associated with HNPCC predisposition - Update of ICG-HNPCC/INSiGHT mutation database. Dis Markers 2004; 20: 269-276.

32. Wijnen J, van der Klift H, Vasen $H$, Khan PM, Menko F, Tops C, Meijers-Heijboer $\mathrm{H}$, Lindhout D, Moller P, Fodde R. MSH2 genomic deletions are a frequent cause of HNPCC. Nat Genet 1998; 20: 326-328

33. Nystrom-Lahti M, Kristo P, Nicolaides NC, Chang SY, Aaltonen LA, Moisio AL, Jarvinen HJ, Mecklin JP, Kinzler KW, Vogelstein $B$. Founding mutations and Alu-mediated recombination in hereditary colon cancer. Nat Med 1995; 1: 1203-1206.

34. Gille JJ, Hogervorst FB, Pals G, Wijnen JT, van Schooten RJ, Dommering CJ, Meijer GA, Craanen ME, Nederlof PM, de Jong D, McElgunn CJ, Schouten JP, Menko FH. Genomic deletions of MSH2 and MLH1 in colorectal cancer families detected by a novel mutation detection approach. Br J Cancer 2002; 87: 892-897.

35. Wagner A, Barrows A, Wijnen JT, van der Klift H., Franken PF, Verkuijlen P, Nakagawa H, Geugien M, Jaghmohan-Changur S, Breukel C, Meijers-Heijboer $H$, Morreau H, van Puijenbroek M, Burn J, Coronel S, Kinarski Y, Okimoto R, Watson P, Lynch JF, de la Chapelle A, Lynch HT, Fodde R. Molecular analysis of hereditary nonpolyposis colorectal cancer in the United States: high mutation detection rate among clinically selected families and characterization of an American founder genomic deletion of the MSH2 gene. Am J Hum Genet 2003; 72: 1088-1 100.

36. Taylor CF, Charlton RS, Burn J, Sheridan E, Taylor GR. Genomic deletions in $\mathrm{MSH} 2$ or $\mathrm{MLH} 1$ are a frequent cause of hereditary non-polyposis colorectal cancer: identification of novel and recurrent deletions by MLPA. Hum Mutat 2003; 22: 428-433.

37. Bunyan DJ, Eccles DM, Sillibourne J, Wilkins E, Thomas NS, Shea-Simonds J, Duncan PJ, Curtis CE, Robinson DO, Harvey JF, Cross NC. Dosage analysis of cancer predisposition genes by multiplex ligation-dependent probe amplification. Br J Cancer 2004; 91: 1155-1159.

38. Di Fiore F, Charbonnier F, Martin C, Frerot S, Olschwang S, Wang $Q$, Boisson $C$, Buisine MP, Nilbert $M$, Lindblom A, Frebourg T. Screening for genomic rearrangements of the MMR genes must be included in the routine diagnosis of HNPCC. J Med Genet 2004; 41 : 18-20.

39. Nystrom-Lahti M, Wu Y, Moisio AL, Hofstra RM, Osinga J, Mecklin JP, Jarvinen HJ, Leisti J, Buys CH, de la Chapelle A, Peltomaki P. DNA mismatch repair gene mutations in 55 kindreds with verified or putative hereditary non-polyposis colorectal cancer. Hum Mol Genet 1996; 5: 763-769.

40. Froggatt NJ, Green J, Brassett C, Evans DG, Bishop DT, Kolodner R, Maher ER. A common MSH2 mutation in English and North American HNPCC families: origin, phenotypic expression, and sex specific differences in colorectal cancer. Med Genet 1999; 36: 97-102.

41. Jager AC, Bisgaard ML, Myrhoi T, Bernstein I, Rehfeld JF, Nielsen FC. Reduced frequency of extracolonic cancers in hereditary nonpolyposis colorectal cancer families with monoallelic hMLH1 expression. Am J Hum Genet 1997; 61: 129-138.

42. Foulkes WD, Thiffault I, Gruber SB, Horwitz M, Hamel N, Lee C, Shia J, Markowitz A, Figer A, Friedman E, Farber D, Greenwood CM, Bonner JD, Nafa K, Walsh T, Marcus V, Tomsho L, Gebert J, Macrae FA, Gaft CL, Paillerets BB, Gregersen PK, Weitzel JN, Gordon PH, MacNamara E, King MC, Hampel H, de La Chapelle A, Boyd J, Offit K, Rennert G, Chong $\mathrm{G}$, Ellis $\mathrm{Na}$. The founder mutation MSH2*1906G—C is an important cause of hereditary nonpolyposis colorectal cancer in the Ashkenazi Jewish population. Am J Hum Genet 2002; 71: 1395-1412

43. Nakagawa $H$, Hampel $H$, de la Chapelle A. Identification and characterization of genomic rearrangements of $\mathrm{MSH} 2$ and MLH1 in Lynch syndrome (HNPCC) by novel techniques. Hum Mutat 2003; 22: 258.

44. Shin YK, Heo SC, Shin JH, Hong SH, Ku JL, Yoo BC, Kim IJ, Park JG. Germline mutations in MLH1, MSH2 and MSH6 in Korean hereditary non-polyposis colorectal cancer families. Hum Mutat 2004; 24: 351.

45. Froggatt NJ, Green J, Brassett C, Evans DG, Bishop DT, Kolodner R, Maher ER. A common MSH2 mutation in English and North American HNPCC families: origin, phenotypic expression, and sex specific differences in colorectal cancer. J Med Genet 1999; 36: 97-102.

46. * Kurzawski G, Suchy J, Kladny J, Safranow K, Jakubowska A, Elsakov P, Kucinskas V, Gardovski J, Irmejs A,Sibul H, Huzarski T, Byrski T, Debniak T, Cybulski C, Gronwald J, Oszurek O, Clark J, Gozdz S, Niepsuj S, Slomski R, Plawski A, LackaWojciechowska A, Rozmiarek A, Fiszer-Maliszewska L, Bebenek M, Sorokin D, Stawicka M, Godlewski D, Richter P, Brozek I, Wysocka B, Jawien A, Banaszkiewicz Z, Kowalczyk J, Czudowska D, Goretzki PE, Moeslein G, Lubinski J. Germline MSH2 and MLH1 mutational spectrum in HNPCC families from Poland and the Baltic States. J Med Genet 2002; 39: E65.

47. * Kurzawski G, Suchy J, Kladny J, Grabowska E, Mierzejewski M, Jakubowska A, Debniak T, Cybulski C, Kowalska E, Szych Z, Domagala W, Scott RJ, Lubinski J. The NOD2 3020insC mutation and the risk of colorectal cancer. Cancer Res 2004; 64: 1604-1606.

48. Frayling IM, Beck NE, Ilyas M, Dove-Edwin I, Goodman P, Pack K, Bell JA, Williams CB, Hodgson SV, Thomas HJ, Talbot IC, Bodmer WF, Tomlinson IP. The APC variants $11307 \mathrm{~K}$ and E1317Q are associated with colorectal tumors, but not always with a family history. Proc Natl Acad Sci USA 1998; 95: 10722-10727. 
49. Lu SL Kawabata M., Imamura T., Akiyama Y., Nomizu T., Miyazono $K$. et al.: HNPCC associated with germline mutation in the TGF-beta type II receptor gene. Nat. Genet.1998, 19, 17-18.

50. Richards FM, McKee SA, Rajpar MH, Cole TR, Evans DG, Jankowski JA, McKeown C, Sanders DS, Maher ER. Germline E-cadherin gene $(\mathrm{CDH} 1)$ mutations predispose to familial gastric cancer and colorectal cancer. Hum Mol Genet 1999; 8: 607-610.

51. Wu Y, Berends MJ, Post JG, Mensink RG, Verlind E, Van Der Sluis $T$, Kempinga $C$, Sijmons $R H$, van der Zee AG, Hollema $H$, Kleibeuker JH, Buys CH, Hofstra RM. Germline mutations of EXO1 gene in patients with hereditary nonpolyposis colorectal cancer (HNPCC) and atypical HNPCC forms. Gastroenterology 2001; 120: 1580-1587.

52. Al-Tassan N, Chmiel NH, Maynard J, Fleming N, Livingston AL, Williams GT, Hodges AK, Davies DR, David SS, Sampson JR, Cheadle JP. Inherited variants of MYH associated with somatic G:C $\longrightarrow$ T:A mutations in colorectal tumors. Nat Genet 2002; 30: 227-232.

53. Munkholm P. Review article: the incidence and prevalence of colorectal cancer in inflammatory bowel disease. Aliment Pharmacol Ther 2003; 18 Suppl. 2: 1-5.

54. Ogura Y, Bonen DK, Inohara N, Nicolae DL, Chen FF, Ramos $\mathrm{R}$, Britton H, Moran T, Karaliuskas R, Duerr RH, Achkar JP, Brant SR, Bayless TM, Kirschner BS, Hanauer SB, Nunez G, Cho JH. A frameshift mutation in NOD2 associated with susceptibility to Crohn's disease. Nature 2001; 41 1: 603-606.

55. Ogura Y, Inohara N, Benito A, Chen FF, Yamaoka S, Nunez G. Nod2, a Nod1/Apaf-1 family member that is restricted to monocytes and activates NF-kappa B. J Biol Chem 2001; 276: 4812-4818

56. Cuthbert AP, Fisher SA, Mirza MM, King K, Hampe J, Croucher PJ, Mascheretti S, Sanderson J, Forbes A, Mansfield J, Schreiber $S$, Lewis CM, Mathew CG. The contribution of NOD2 gene mutations to the risk and site of disease in inflammatory bowel disease. Gastroenterology 2002; 122: 867-874.

* In these papers information was used about families diagnosed by detecting the $\mathrm{MSH} 2$ and $\mathrm{MLH} 1$ gene mutation as part of a postdoctoral degree. 